\title{
Employee Stock Options: A Standard Setting Saga
}

Denise A. Jones, Ph.D., College of William and Mary, USA

Kimberly J. Smith, Ph.D., College of William and Mary, USA

\begin{abstract}
In this case, you will examine one of the most dramatic standard-setting sagas of our time: the setting of accounting standards related to employee stock options (ESOs). In particular, you will explore the important issues addressed by each standard, as well as the subsequent challenges that developed - which, in turn, led to the issuance of even more accounting guidance.
\end{abstract}

Keywords: Executive Compensation; Employee Stock Options; Teaching Methods

\section{INTRODUCTION}

stock option gives the holder the right, but not the obligation, to purchase shares of the company's
stock (by exercising the option) at a specified price (the exercise price or strike price) for a specified
period of time (the life of the option). The holder of the option hopes to exercise the option when the company's stock price is higher than the exercise price. Upon exercise, the holder pays the exercise price and receives a share of stock for each share covered by the option. Options are described as in the money when the company's stock price is higher than the strike price, at the money when the company's stock price is equal to the strike price, and out of the money or underwater when the company's stock price is below the strike price.

An option has both intrinsic value and time value. The intrinsic value is the amount that could be earned if the option were exercised and the stock sold - that is, the difference between the stock price and the strike price at any given point in time. However, even if the intrinsic value is zero (i.e., if the strike price is exactly equal to the current stock price), the option still has time value because there is the possibility that the stock price will rise over time.

The time value of an option increases with the volatility of the underlying stock price. This is because the option holder benefits from positive stock movements but is protected from negative price movements. Thus, if a company has more volatility in its stock prices, the holder of an option on that company's stock has the opportunity to garner larger gains. Options with longer lives also have greater value, as there is a longer time period over which to achieve positive price movements. In addition, the option is more valuable when the risk-free rate of return (e.g., the return on Treasury securities) is higher, because instead of spending the money now (to pay the exercise price and obtain the share of stock), the option holder can invest those funds in a risk-free asset and exercise the option at a later date. Finally, the option's value decreases with the opportunity costs of holding the option; for example, the option holder forgoes receiving company dividends by holding the option rather than exercising it and obtaining the stock.

\section{EARLY HISTORY OF STOCK OPTIONS AS COMPENSATION}

Granting stock options to employees became increasingly more prevalent during the 1950s and early 1960s. ${ }^{1}$ Call (1969) notes that 1.8\% of New York Stock Exchange companies had stock option plans in 1950, while

\footnotetext{
${ }^{1}$ Employee stock options (ESOs) are similar to exchange-traded options in many ways, but their terms are much longer-often as long as ten years. ESOs also differ in that there is a vesting period before the options can be exercised, and the employees are (almost always) restricted from selling them to a third party.
} 
$63.3 \%$ of companies had such plans in 1961. Some companies grant ESOs to all employees, while others focus their option grants on senior management. Start-up companies often argue that options are an especially critical component of their compensation packages, as they are short on cash but wish to attract high quality employees. Technology companies have been particularly keen on offering their employees stock options, and many continue to do so even after they become very large.

Ratliff $(2005,38)$ argues that the incentive to begin granting stock options to employees was originally related to the favorable tax treatment such options received:

Use of qualified plans allowed for capital gain treatment by the employee upon the subsequent sale of stock obtained through the plan if held for three years. Because the top marginal personal tax rate on ordinary income at the time was $70 \%$, compared to a capital gains rate of $25 \%$, this was a particularly attractive form of compensation for the executive.

However, some believed that stock options were a potential tool to hide compensation from shareholders. For example, Dillavou $(1945,321)$ argued that:

The directors and the employee may desire to cover up from the stockholders the magnitude of the salary paid and use this particular camouflage to effect that result. By dressing the compensation in this new guise, it may become unrecognizable to most of the stockholders and to the public generally.

Historically, a large proportion of employee stock options have been written as fairly straightforward instruments, with a fixed exercise (strike) price and a fixed life. However, as companies became more sophisticated in designing their incentives, some desired to incorporate more complex structures in order to better tie the incentives of employees to those of shareholders. For example, an indexed option is structured so that the strike price increases along with some general market index. Such a design rewards employees only for company stock performance over and above the performance of the overall market. Other types of options may be structured so that the strike price and/or the number of options granted are tied to other performance measures, such as company earnings.

\section{ACCOUNTING ISSUES RELATED TO STOCK OPTIONS}

There are four basic accounting issues related to employee stock options:

(1) Should companies recognize an expense in the income statement related to employee stock options?

(2) How should the cost associated with these options be measured?

(3) Over what period of time should this cost be recognized as an expense in net income?

(4) If a company does recognize expense — by debiting "Employee Stock Option Expense"—what is the credit?

Consider a company granting its employees 100,000 options, valued at $\$ 15$ each. If both of these amounts (i.e., the number of options granted and the value of each option) are known, total compensation cost can be calculated fairly simply as a price * quantity (i.e., $\mathrm{P} * \mathrm{Q}$ ) calculation. In this case, $\mathrm{P}=\$ 15$ and $\mathrm{Q}=100,000$, resulting in total compensation cost of $\$ 1.5$ million. $^{2}$

Now back to the first question: should the $\$ 1.5$ million be recognized as an expense on the company's income statement? Some argued that employee stock options are clearly an expense, because they are given to employees in exchange for their services. For example, Warren Buffet noted in his 1998 letter to Berkshire Hathaway shareholders:

If options aren't a form of compensation, what are they? If compensation isn't an expense, what is it? And, if expenses shouldn't go into the calculation of earnings, where in the world should they go?

\footnotetext{
${ }^{2}$ Note that this example illustrates the calculation of total compensation cost, not compensation expense. However, the compensation expense recognized in any particular period would be based on this total compensation cost, as is discussed below.
} 
Others pointed out that options should not be expensed because there is no related cash outflow to granting these options - the company merely issues stock — and furthermore, that the company actually receives cash (i.e., the exercise price) when the options are exercised.

The second question relates to how the $\$ 15$ and the 100,000 were determined. Many argue that it is impossible to accurately determine the fair value of stock options, and thus any value is so unreliable as to be seriously misleading to investors. In contrast, others argue that there are many estimates inherent in financial statements and this is simply one more. There is also substantial disagreement about when the valuation should take place. Some argue that options should be valued at the date of grant; others argue for the date the options vest; and still others for the date of exercise. It may surprise you to know that even the number of options used to calculate total compensation is debated. For example, companies could use the number of options granted (i.e., the 100,000), the number of options that eventually vest, or the number of options eventually exercised.

The third question relates to when the $\$ 1.5$ million should be recognized as an expense in the income statement. To achieve matching of revenues and expenses, the expense would be allocated to the period or periods in which the company receives the benefits from granting the options. However, determining this period may not be straightforward. The following questions arise: Are the options compensation for past services, such that the entire $\$ 1.5$ million should be recognized as an expense on the date of grant? Does the company benefit from the employees' services over the time it takes the options to vest? Or does the company benefit for the entire time an employee works for the company?

Finally, assuming the company records compensation expense for ESOs (i.e., a debit), what is the credit in the journal entry? Specifically, when the company debits expense, should it credit shareholder equity or a liability? Many argue that if the company is giving employees an equity instrument, then the credit should obviously be to equity. However, others argue that granting employee stock options creates a liability, especially if the company has to repurchase shares of stock to prevent the dilution of shares outstanding. ${ }^{3}$

The fundamental questions posed above have resulted in some of the most bitterly fought battles in the history of accounting standard setting. Companies, auditors, standard-setters, regulators, Congress, and even the occasional U.S. President have taken sides on this issue during the decades-long debate that has surrounded the accounting for stock options.

\section{EARLY GUIDANCE ON STOCK OPTION ACCOUNTING}

\section{Accounting Research Bulletin No. 43, Chapter 13 (ARB 43)}

In 1953, paragraph 1 of Chapter 13, Section B of Accounting Research Bulletin No. 43, "Compensation," stated in part (AICPA 1953):

The practice of granting to officers and other employees options to purchase or rights to subscribe for shares of a corporation's capital stock has been followed by a considerable number of corporations over a period of many years. To the extent that such options and rights involve a measurable amount of compensation, this cost of services received should be accounted for as such. The amount of compensation involved may be substantial and omission of such costs from the corporation's accounting may result in overstatement of net income to a significant degree.

In addition, the standard (as cited in Bomeli 1962) states:

Although there is, from the standpoint of the grantee, a value inherent in a restricted future right to purchase shares at a price at or even above the fair value of shares at the grant date, the committee believes it is impracticable to measure any such value... The value to the grantee and the related cost to the corporation of a restricted right to purchase shares at a price below the fair value of the shares at the grant date may for the purposes here under discussion be taken as the excess of the then fair value of the shares over the option price [emphasis added].

\footnotetext{
${ }^{3}$ In fact, some point out that there is a (potentially hidden) cash cost to ESOs if the company repurchases shares of stock to prevent dilution (see, e.g., Ciccotello et al. 2004; Meyer and Fassier 2004).
} 
Thus, ARB 43 required the recognition of compensation expense only for options that were in the money at the grant date, based on the company's estimate of the fair value of its stock. ${ }^{4}$

ARB 43 also required disclosures about stock option plans. Many argued that since many details about the options were disclosed, investors should be adequately informed of all relevant information. Others disagreed, sometimes vociferously, such as Bomeli (1962, p.743):

My own reaction is the accounting equivalent of "Horsefeathers!!" Accountants have pharisaically and devotedly avoided the spirit of the requirements, which for us is fairly typical. It must be obvious that despite our pious protestations as to the impracticability of measuring the value "inherent in a restricted future right to purchase shares at a price at or even above the fair value of the shares at the grant date," compensation (with a tremendous tax advantage) is intended for corporate executive or there would be no reason for offering them-and that intention does not need even to be thinly veiled.

As you can see, there was passionate disagreement about this issue before most readers of this case were even born!

\section{Accounting Principles Board Opinion No. 25 (APB 25)}

In 1972 the Accounting Principles Board issued Opinion No. 25, "Accounting for Stock Issued to Employees," which was intended to improve the accounting for stock options, in part, by requiring that companies use the quoted market price of the stock (rather than the company's estimate of the fair value of the stock) when they calculated the intrinsic value. Specifically, APB 25 states that companies would be required to measure the compensation expense related to stock options as "the quoted market price of the stock at the measurement date less the amount, if any, that the employee is required to pay (APB 1972, par. 10)." When it was issued, this standard was believed to improve the accounting for many stock options - which at that time were regularly in the money at the date of grant - by requiring companies to expense the full intrinsic value of the option. You should note, however, that the time value of the option continued to be ignored under this standard.

"Fixed" vs. "Variable" Accounting

APB 25 also specified that total compensation cost be determined on the measurement date, which is the "first date on which are known both (1) the number of shares that an individual employee is entitled to receive and (2) the option or purchase price, if any" (APB 1972, par. 10(b)). Note that for options with fixed exercise prices and a fixed life, this date would be the grant date. This type of option came to be known as a "fixed" option and APB No.25 perpetuated an "exception" for fixed options granted at the money - that is, with an intrinsic value of zero. For these options, compensation expense measured under APB 25 would continue to be zero, as it was under ARB 43.

The Opinion also addressed the accounting for more complex options. Specifically, the standard states that:

If the measurement date is later than the date of grant or award, an employer corporation should record the compensation expense each period from date of grant or award to date of measurement based on the quoted market price of the stock at the end of each period (APB 1972, I13).

For example, if a company issued options such as the indexed options described earlier, the exercise price would not be fixed at the grant date and thus the measurement date would typically be later than the grant date. In this case, APB 25 specified that the total compensation cost should be recalculated at every reporting date based on the stock price at that date. If the company's stock price changed, compensation expense under this option would

\footnotetext{
${ }^{4}$ Note that although the standard setters use the term fair value in this standard, fair value was not necessarily viewed to be the market price of the stock on the date of grant. Average prices were used and/or discounts applied. Thus, the wording of this standard allowed companies to grant options where the current stock price was, for example, $\$ 30$ and the exercise price was $\$ 25$, but to recognize less than $\$ 5$ in compensation expense.
} 
likely not be zero, but would reflect the ups and downs (i.e., the volatility) of the company's stock price from period to period. This treatment is often referred to as "variable" accounting, and was viewed as very undesirable by companies, as the expense may vary quite substantially over time.

\section{An Example}

To illustrate the difference between fixed and variable accounting, consider a January 1 grant of 100 options with an exercise price (or strike price) of $\$ 25$ and a vesting period of five years. Assume the stock price was $\$ 30$ on the date of grant, $\$ 28$ at the end of the first year, $\$ 34$ at the end of year two, and $\$ 27$ at the end of year three. If the option received "fixed" accounting, total compensation cost would be $\$ 500[(\$ 30-\$ 25) * 100]$ and would be allocated over the five-year vesting period so that $\$ 100$ [\$500/5] in compensation expense would be recognized each year. ${ }^{5}$

If the option received "variable" accounting, the total amount of compensation cost at the end of year one would be $\$ 300$ [ $\left.\$ 28-\$ 25)^{*} 100\right]$, resulting in compensation expense for year one of $\$ 60$ [\$300/5]. At the end of year two, total compensation cost would be $\$ 900\left[(\$ 34-\$ 25)^{*} 100\right]$, resulting, at first glance, in compensation expense of $\$ 180$ [\$900/5] per year. However, this calculation seems to imply that the $\$ 60$ expensed in year one was incorrect. Under APB 25, you would deal with this change prospectively. Thus, year two compensation expense would be calculated such that $2 / 5$ (i.e., two years out of the five year vesting period) of the newly calculated total compensation cost would be recognized by the end of year two. You would not go back and change the year-one expense, but would instead expense enough in year two to cumulatively correct the total. Thus, compensation expense for year two would be $\$ 300$ [\$900*2/5-\$60]. ${ }^{6}$ Year three compensation expense would be a negative $\$ 180$, calculated as follows: total compensation cost of $\$ 200\left[(\$ 27-\$ 25)^{*} 100\right]$, multiplied by $3 / 5$, less $\$ 300$ expense already recognized. ${ }^{7}$

You may also be wondering if this process continues for the entire life of the option. For a market-indexed option, the answer is 'yes,' as the exercise price is not fixed until the option is exercised. However, for other types of "variable" options, if the exercise price and the number of shares become fixed at some point, then a measurement date occurs, the dollar amount of total compensation expense is finalized, and no further adjustments are made. ${ }^{8}$

If you are thinking that this process sounds annoying, you would be in agreement with most accountants and financial statement preparers. In addition, as you can see from the example, variable accounting may lead to substantial volatility in compensation expense and thus in earnings (i.e., compensation expense would go up and down along with the company's stock price). You are probably not surprised to hear that, with the advent of APB 25 , companies became very enthusiastic about issuing simple options with fixed lives and strike prices - and issuing them at the money. Designing option plans in this way allowed these companies to avoid variable accounting, and to avoid recognizing any expense for ESOs.

\section{Financial Accounting Interpretation No. 28 (FIN 28)}

In 1976, the SEC issued insider trading rules that required employees exercising options to hold the stock for six months before selling it, thus tying up their capital and exposing them to additional risk (i.e., that the stock price would drop during the holding period). These rules, along with changes enacted in the tax laws, led to the creation of new types of plans. One example was the stock appreciation right (SAR). A SAR has similar characteristics to an ESO, but an employee exercising a SAR would not pay the exercise price and would not receive the stock. Instead, upon exercise, the company would write the employee a check for the appreciation in the stock (i.e., the stock price on the date of exercise less the designated strike price).

\footnotetext{
${ }_{6}^{5}$ Note: If this option had been granted when the stock price was $\$ 25$, total compensation cost would have been zero.

${ }^{6}$ Alternatively, the $\$ 300$ may be calculated as the new amount of $\$ 180$ for year two, plus an incremental $\$ 120$ to adjust year one.

7 This example is very simplistic and does not capture many complexities that could occur in an option qualifying for variable accounting. For example, the exercise price could change each year, instead of remaining at $\$ 25$ throughout the life of the option. APB 25 is not clear about how to treat such changes (i.e., whether the new exercise prices would be used in the calculations). For all variable accounting calculations in this case, we will use the exercise price and number of options expected to be in effect each period.

${ }^{8}$ Note that the measurement date could occur before or after the options vest.
} 
The emergence of SARs raised two important issues. First, should a SAR that is issued at the money receive "fixed" accounting or "variable" accounting under APB 25? Second, does the fact that the company will pay the employee cash instead of giving them shares of stock mean that granting this instrument results in a credit to liability rather than equity? Financial Accounting Interpretation No. 28 was issued and clearly answered the first question-SARs should receive variable accounting - but did not address the second. However, even though financial statement preparers now had more guidance about how to account for SARs, FIN 28 only further exacerbated the inconsistencies introduced by APB 25.

\section{STOCK OPTION ACCOUNTING REVISITED}

Over the years, substantial debate ensued as critics of APB 25 argued that the accounting used by most companies did not reflect the economics of their pay plans. Specifically, under APB 25 a "fixed" option issued at the money would result in zero compensation expense, while a "variable" option issued at the money (likely worth substantially less than its fixed counterpart) would result in compensation expense. With the issuance of FIN 28, it was now also the case that a company issuing fixed stock options at the money would recognize zero compensation expense, while if the company had issued SARs with exactly the same terms, the SARs would receive variable accounting (and thus expense would be recognized).

Defenders of APB 25 continued to argue that there was no practical way to estimate the fair value of these options. However, in 1973 Fisher Black and Myron Scholes (in collaboration with Robert Merton) published an important research study describing a new method to value stock options (for which they received a Nobel Prize in 1997). The Black-Scholes model is a formula that calculates the value of an option based on its strike (exercise) price, the price of the stock, the life of the option, the expected volatility of the stock, the expected risk-free rate of return, and the expected dividend yield of the company. This model incorporates both the option's intrinsic value and time value.

The Black-Scholes model is an example of a closed-form model; one limitation of these types of models is that they do not allow the parameters (such as expected volatility or the exercise price) to change over time. Thus, this model has difficulty valuing certain more complex options. Another type of option pricing model is the binomial (or lattice) model. With this model the potential paths that the stock price can take over the life of the option are mapped out and the option's value is based on the probability that the stock price rises or falls. In this model, the parameters can change each period. For example, the exercise price can be different for each period. This allows more complex options to be valued, such as options where the exercise price changes over time. In addition, the model can more easily reflect the likelihood that employees will exercise the option early (e.g., before the end of its life). For example, early exercise of the option can be linked to changes in stock prices and allows for assumptions about when an employee would exercise - such as when the stock price reaches a value of two times the exercise price.

Many have also criticized the use of the Black-Scholes model to value ESOs because it does not incorporate other important restrictions inherent in a typical employee stock option, such as the inability of the employee to sell the option and the inability of the employee to exercise the option during the vesting period, among others. Although the binomial model has the ability to incorporate some of these aspects, it is substantially more complex to implement. Thus, during this time most companies - and most accountants - did not view option valuation models as practicable. Nonetheless, the increasing credibility of these models did start the profession down the path of considering whether obtaining reliable estimates of the fair value of employee stock options was possible.

In 1984, the FASB added a project to its agenda to reconsider APB 25. They subsequently issued an Invitation to Comment that laid out many of the issues to be discussed. As the Board continued to discuss the accounting for stock options, they became increasingly sidetracked by the issue of whether ESOs were equities or liabilities. The conceptual framework definitions of liabilities and equities were not clear enough for the Board to unequivocally conclude, and they spent substantial time on this issue. In 1992, the Board decided that the conceptual framework should really be updated, but that they would go with equity treatment for stock options. The Board then resumed work on the stock option project. 
In 1993 the FASB issued an Exposure Draft, Accounting for Stock-Based Compensation, which proposed that compensation expense be recognized in income based on the fair value (i.e., not the intrinsic value) of the option at the grant date. Public outcry against the proposal was fierce, with executives claiming that the stock option proposal would "hammer the profitability of US companies, discourage the use of stock incentives, and even damage the American spirit of innovation" (Shao 1994). The FASB received 1,789 comment letters, most of which strongly objected to the recognition of compensation expense based on the fair value of employee stock options. As you might guess, the staunchest opposition was from emerging growth and high technology companies. A typical assertion about the damage that expensing stock options would cause to US companies was made by the cofounder and chairman of Home Depot, Bernard Marcus, who claimed that:

[I] the proposal had been in effect since Home Depot went public in 1981, the company would be 10 percent of its current size. There's no way we could have hired, motivated and brought people along (Shao 1994).

The Wall Street Journal later summarized the results of the FASB's proposal as follows (also see Beresford (1995):

The vote produced a political tsunami that started in Silicon Valley, gathered force in Washington, and slammed into Norwalk, Conn., where the accounting board is based.

In 1994, thousands of high-tech workers gathered in Northern California for a raucous pro-options demonstration called the "Rally in the Valley," sporting T-shirts and placards with such slogans as "Stop FASB!" and "Federal Accounting Stops Business." The new accounting rule would "destroy the high-tech industry," warned the head of the American Electronics Association. The high-tech sector circulated studies predicting that corporate profits would fall by 50\% and that capital would dry up as a result of the new rule. More than 100 high-tech executives flew to Washington to work Capitol Hill.

The Clinton administration weighed in against the FASB. So did institutional-investor groups, who said the rule change would muddy financial statements. A nonbinding resolution opposing the FASB rule change passed the Senate by a vote of 88-9. Its sponsor, Sen. Joseph Lieberman, a Connecticut Democrat, later proposed legislation that would have, in effect, put the FASB out of business. The Business Roundtable, a group made up of major corporate leaders, threatened to refuse to adhere to FASB decisions. (Hitt and Schlesinger 2002)

The brouhaha went on and on, continuing to escalate rather than dying down. Arthur Levitt, the newly appointed Chairman of the SEC, in an interview with Frontline, recalls,

When I came to the SEC, this new FASB rule to expense stock options had galvanized the American business community and brought literally hundreds of CEOs to my office in Washington to urge me to prevent the FASB from going ahead with this proposal. ...

But what happened during the course of this fierce debate and dialogue was that the Congress changed, and Newt Gingrich brought to power a group of congress people who were determined to keep FASB from enacting this rule proposal. My concern was that if Congress put through a law that muzzled FASB, that would kill independent standard setting. So I went to FASB at that time, and I urged them not to go ahead with the rule proposal...It was probably the single biggest mistake I made in my years at the SEC... ${ }^{9}$

\section{Statement of Financial Accounting Standard No. 123 (SFAS No. 123)}

In December of 1994, the FASB yielded to the pressure and voted to recommend, but not require companies to expense the fair value of their ESOs. Statement of Financial Accounting Standard (SFAS) No. 123, "Accounting for Stock-Based Compensation," was issued in October of 1995. Specifically, SFAS No. 123 states (FASB 1995, Il11):

\footnotetext{
9 This interview was conducted by FRONTLINE correspondent Hedrick Smith on March 12, $2002 . \quad$ See http://www.pbs.org/wgbh/pages/frontline/shows/regulation/congress/.
} 
This Statement provides a choice of accounting methods for transactions with employees that are within the scope of Opinion 25. Paragraphs 16-44 of this Statement describe a method of accounting based on the fair value, rather than the intrinsic value, of an employee stock option or a similar equity instrument. The Board encourages [emphasis added] entities to adopt the fair value based method of accounting, which is preferable to the Opinion 25 method...However, an entity may continue to apply Opinion 25 in accounting for its stock-based employee compensation arrangements. An entity that does so shall disclose pro forma net income and, if presented, earnings per share, determined as if the fair value based method had been applied in measuring compensation cost...

As you might imagine, companies did not leap at this opportunity to adopt the recognition provisions of SFAS No. 123 (i.e., to recognize compensation expense for ESOs in net income). Instead, most companies chose to continue to use APB 25 to determine how much expense to include in the income statement (usually zero). However under SFAS No. 123, these companies were required to disclose the fair value of its ESOs in the financial statements footnotes. The good news was that this information was now available to shareholders, even if it did reside in the footnotes.

However, the FASB was not happy with this outcome, and publicly documented its political compromise in the Basis for Conclusions section of SFAS No. 123 (FASB 1995, I/ 60 and 61):

The debate on accounting for stock-based compensation unfortunately became so divisive that it threatened the Board's future working relationships with some of its constituents. Eventually, the nature of the debate threatened the future of accounting standards setting in the private sector.

The Board continues to believe that financial statements would be more relevant and representationally faithful if the estimated fair value of employee stock options was included in determining an entity's net income, just as all other forms of compensation are included. To do so would be consistent with accounting for the cost of all other goods and services received as consideration for equity instruments. The Board also believes that financial reporting would be improved if all equity instruments granted to employees, including instruments with variable features such as options with performance criteria for vesting, were accounted for on a consistent basis. However, in December 1994, the Board decided that the extent of improvement in financial reporting that was envisioned when this project was added to its technical agenda and when the Exposure Draft was issued was not attainable because the deliberate, logical consideration of issues that usually leads to improvement in financial reporting was no longer present. Therefore, the Board decided to specify as preferable and to encourage but not to require recognition of compensation cost for all stock-based employee compensation, with required disclosure of the pro forma effects of such recognition by entities that continue to apply Opinion 25.

Given all the hoopla about expensing employee stock options, you might be wondering whether the expense amounts were material for the affected companies. Botosan and Plumlee $(2001,312)$ studied the disclosures for a group of 100 growth companies during the years 1996-1999 and found that

...stock option expense has a material effect on measures of firm performance for the sample [of Fortune magazine's “America's Fastest-Growing Companies"]. In the most recent fiscal year analyzed, we document a median reduction of 14.0 percent in earnings per share (EPS) and a median reduction of 13.6 percent in return on assets (ROA) due to stock option expense. Moreover, we find that the magnitude of stock option expense should grow larger, at least for the near future, thereby adding to the significance of the figures involved.

Thus, stock compensation expense was found to be a material item for many companies. However, to reiterate, most companies chose to present this amount only in their footnotes.

Determining Compensation Expense under SFAS No. 123

Recall that two of the important questions related to determining compensation expense are: how should compensation cost (i.e., P and Q) be measured, and when should the expense be recognized in earnings. SFAS No. 123 states that the objective of the measurement process (i.e., measuring P) is to estimate the fair value based on the stock price at the grant date (1995 I17). The new standard also describes how to estimate P using a fair value approach (FASB 1995 I19): 
The fair value of a stock option (or its equivalent) granted by a public entity shall be estimated using an optionpricing model (for example, the Black-Scholes or a binomial model) that takes into account as of the grant date the exercise price and expected life of the option, the current price of the underlying stock and its expected volatility, expected dividends on the stock (except as provided in paragraphs 32 and 33), and the risk-free interest rate for the expected term of the option.

SFAS No. 123 also states that Q shall be based on the number of instruments that eventually vest (FASB 1995 I26). Finally, compensation expense for a particular period continues to be determined by allocating total compensation cost over the periods that services are rendered, which is typically the vesting period (FASB 1995, q[30).

SFAS No. 123 also provides guidance about many other issues. For example, guidance is provided regarding how to deal with options that have various conditions, such as different exercise prices for different levels of future performance. The valuation of more complex options such as these can be more difficult using a fair value approach than when using simple intrinsic values, as in APB 25. Guidance is also provided about the assumptions needed to estimate option fair values using valuation models. For example, SFAS No. 123 specifies the use of the expected life of the option, rather than its legal life, and also includes discussion of how to determine this expected life.

\section{ACCOUNTING CONSEQUENCES OF STOCK MARKET DECLINE}

In the late 1990s, the stock market dropped precipitously and companies were faced with a new challenge. Their employees were holding options that were now drastically underwater. Companies began "repricing" options, that is, reducing the exercise prices of outstanding options so they were within reach of the now-lower company stock prices. Other common modifications of employee stock options included extending the life of the option or accelerating the vesting of the option.

Companies still applying APB 25 were very concerned about the accounting consequences of repricing. APB 25 seemed to imply that changes in the exercise price would result in a new measurement date, and possibly in variable accounting, but the standard was not clear. The FASB had hoped that SFAS No. 123 would supersede APB 25 altogether, eliminating the necessity of dealing with these APB 25 implementation issues. However, since APB 25 was still in the picture, the FASB was now faced with many questions related to repricing and numerous other issues. The Emerging Issues Task Force (EITF) had also been discussing a long series of questions about the application of APB 25. The FASB now compiled a subset of these issues into FIN 44, discussed below.

\section{Financial Accounting Interpretation (FIN) No. 44}

Financial Accounting Interpretation No. 44 provided additional interpretation of APB 25. FIN 44 focused on several issues, among them the accounting consequences of repricings. The specific guidance provided by FIN 44 in paragraphs 38 and 39 is provided in question/answer format, as shown below (FASB 2000a):

Question 11(a)-What is the accounting consequence of a modification that reduces the exercise price of a fixed stock option award (commonly referred to as repricing)?

Interpretation-If the exercise price of a fixed stock option award is reduced, the award shall be accounted for as variable from the date of the modification to the date the award is exercised, is forfeited, or expires unexercised.

FIN 44 was based on the idea that a new measurement date had been established by the modification, thus "invalidating" the original use of the exception for fixed options. However, this interpretation was viewed as punitive by many because it required variable accounting for the entire remaining life of the option. After FIN 44 was issued, the number of option repricings declined dramatically (Schroeder and Simon 2001).

Companies had also begun implementing another tactic to address the same problem (i.e., drastically underwater options): canceling options with high exercise prices and replacing them with new grants of options with 
lower exercise prices. FIN 44 also addressed this practice by requiring variable accounting for replacement stock option awards that were "combined" with the cancellation of another award (FASB 2000a, II 43). Thus, companies could not get around the repricing guidance by simply canceling one option grant and replacing it with another.

One obvious question was how to conclude that the two option grants were "combined." FIN 44 also addressed this question (FASB 2000a, II45):

An option award cancellation (settlement) shall be combined with another option award and results in an indirect reduction of the exercise price of the combined award if another option with lower exercise price than the canceled (settled) option is granted to the individual within the following periods:

a. $\quad$ The period prior to the date of the cancellation (settlement) that is the shorter of (1) six months or (2) the period from the date of grant of the canceled or settled option

$b$. The period ending six months after the date of the cancellation (settlement).

The response to this "bright line test" was almost immediate. The Wall Street Journal reported on many companies' new strategies as follows (Brown 2001):

One way to avoid triggering this potentially costly rule [FIN 44] is to cancel the old options and then reissue them six months and one day [emphasis added] later, at the market price that day. This has become the strategy du jour for companies that want to reprice their employee stock options. It costs the company nothing. And-unlike the alternatives of granting new options at current prices or just making stock grants to employees as some companies have done-it doesn't dilute existing shareholders.

Companies have embraced these plans since Sprint, the phone company, launched the first one this past November. 'Now it's a jailbreak-people are writing them as fast as they can,' says Patric McGurn, vice president at Institutional Shareholder Services [ISS], which advises institutional investors on how to vote on proxies. ISS estimates that at least 22 companies announced these six-months-and-a-day plans in May, nearly twice the number in April, and more than three times those in March.

As this article also notes, these six-months-and-a-day, or " $6+1$," plans provide employees with the incentive to dampen the company stock price during the six month waiting period. As the author quips, "Your pay is based heavily on employee stock options. So you are keeping your fingers crossed, hoping your stock sinks like a rock?"

Companies faced tough choices. If they reissued stock options right away, there were accounting consequences as described above in FIN 44. If they wait six months to reissue stock options, then this may create incentives for employees to depress stock prices. One solution to this problem would be for the company to compensate the employees for any increases in the stock price during the waiting period. Anticipating this, the FASB specified in FIN 44 that any promises to compensate the employee for increases in the market price of the stock automatically results in variable accounting for the replacement award, irrespective of the time that has elapsed between cancellation and replacement (FASB 2000a, I/47). Note that the FASB was not opposed to the goal of providing appropriate incentives to employees; they were concerned with recognizing compensation expense when changes were made that increased the value of the award. However, as you can imagine, companies immediately began using creative ways to indirectly compensate employees for stock prices increases. This issue, along with several others, was addressed by the Emerging Issues Task Force.

\section{Emerging Issues Task Force (EITF) 00-23}

The EITF had continued to debate the remaining outstanding issues related to the implementation of APB 25 and added several issues that arose in response to FIN 44. In total, the EITF reached consensus on 51 separate issues, many with subparts. This consensus is denoted as EITF 00-23 and titled "Issues Related to the Accounting for Stock Compensation under APB 25 and FIN 44.” 
As discussed above, one new issue created by FIN 44 related to indirectly compensating employees for increases in stock price between the time that one stock option was cancelled and another was awarded at least six months after the cancellation. One creative way to indirectly compensate employees was to design the new option to already be in-the-money at the date of grant. EITF 00-23 address this issue as follows (FASB 2000b, I/103).

The Task Force reached a consensus that a grant of an in-the-money option award subsequent to a cancellation of a previous option award creates a presumption that an agreement or implied promise existed to compensate the grantee for increases in the market price of the stock after the cancellation date (even if the market price of the stock has not increased) and, therefore, results in variable accounting for the new award. This presumption may be overcome if the relevant facts and circumstances clearly indicate that the in-the-money grant is not related to the prior cancellation.

This is just one example from EITF 00-23. As you can imagine, with 51 separate issues to address, the document is quite lengthy! At this point, with guidance coming simultaneously from APB 25, FIN 28, FIN 44, EITF 00-23, and SFAS No. 123, among others, the accounting for employee stock options had grown quite complex.

\section{STOCK OPTION ACCOUNTING: ROUND TWO}

At the same time that stock option accounting was growing unwieldy, public sentiment about financial reporting was changing. Enron and the other major financial reporting failures in the early years of the new millennium increased the demand for transparent reporting. As a result, some public companies began to voluntarily adopt the fair value recognition provisions of SFAS No. 123 - arguably as a show of "good faith" (DiStefano 2002). In addition, in November 2002, the International Accounting Standards Board (IASB) issued an exposure draft requiring the recognition of the fair value of share-based payments (e.g., stock options) as an expense. In 2001, when this exposure draft was still an agenda topic, the Association for Investment Management and Research (now the CFA Institute) surveyed their members about the proposal. The survey found that over 80 percent of financial analysts believed that stock options granted to employees are a form of compensation and should be recognized as an expense on the income statement (Business Wire 2001). The FASB began receiving numerous requests from investors and regulators to revisit SFAS No. 123 with an eye toward requiring fair value recognition of stock options.

In March of 2003, the Board again added this issue to their agenda and began discussions. Immediately, companies began lobbying to prevent the accounting standard, making similar arguments to those made in 1993most notably that requiring the fair value of stock options to be expensed would inhibit innovation, increase the cost of capital, make US companies less competitive, and make it more difficult to attract employees. Executives of high technology firms claimed that the expensing of stock options would make it more costly to hire US employees and would increase incentives for outsourcing labor overseas. "Make us expense options, they warn, and the already worrisome leaching of tech positions abroad will only accelerate - even if the economy improves "(Hamm et al. 2003)." Many continued to argue that there was no way to reliably measure the fair value of stock options. However, this argument was less convincing the second time around, in part due to academic studies showing that option pricing models can provide very good estimates of value for traded options (see, e.g., Carpenter 1998; Marquardt 2002; Bettis et al. 2005).

In late 2003, Representative Richard Baker (R-LA) sponsored a bill in the U.S. House of Representatives (short-) titled the "Stock Option Accounting Reform Act," that would require the expensing of the fair value of all options granted to the CEO plus the four most highly compensated executive officers. At first glance, this bill appears to support the FASB's position.

However, note that the bill applied to only the top five executives. Thus, any compensation cost related to all other employees is ignored. The bill also states: "To the extent that an option pricing model, such as the BlackScholes method or a binomial model, is used to determine the fair value of an option, the assumed volatility of the 
underlying stock shall be zero."10 Among other things, the bill also prohibited the SEC from recognizing as "generally accepted" any accounting principle that does not comply with this bill—such as the FASB's revision of SFAS No. 123 !

On March 3, 2004 the U.S. House Subcommittee on Capital Markets, Insurance, and Government Sponsored Entities held hearings on this bill. Representative Baker (R-LA) introduced the topic, noting:

H.R. 3574 preserves the opportunity to take dreams and turn them into reality and success, but I believe would eliminate the opportunity for manipulative management to flip options for fortunes.

Arthur Coviallo, President and CEO of RSA Security, testified:

The mandatory expensing standard that FASB intends to put into place will force demonstrably inaccurate and unavailable numbers into the financial statements. Let me give you an example from my own company. I am very proud of the fact that we engineered a successful turnaround last year, generating \$39 million in operating cash flow and \$14 million in after-tax earnings on a GAAP basis, that is, GAAP without expensing stock options. Had we expensed stock options we would have recorded a \$21 million loss, a \$21 million loss [emphasis added]. That is a $\$ 36$ million swing had we expensed stock options. convinced?

Coviallo seems convinced by this argument that stock options should not be expensed. Are you

In the midst of this controversy, on March 31, 2004, the FASB issued the Exposure Draft, Share-Based Payment, and established a comment period that ended in June of 2004. The Board stuck to their guns and proposed expensing the fair value of ESOs. In response, they received a record 14,239 comment letters. This level of response to an accounting standard was unprecedented.

On April 20, 2004 the U.S. Senate Committee on Homeland Security and Governmental Affairs Subcommittee on Federal Financial Management, Government Information, and International Security held its own hearings on the stock option bill. During the hearings, Senator Daniel K. Akaka (D, HI) asked the Honorable Paul A. Volcker (Chairman, International Accounting Standards Committee Foundation, and former Chairman, Board of Governors, Federal Reserve System) the following question: ${ }^{11}$

Chairman Volcker, there are some opponents of the FASB proposal who argue that expensing stock options would slow job creation and potentially increase the use of outsourcing. What is your evaluation of these arguments?

Volcker carefully leaned forward and replied succinctly, with a deadpan expression:

They are not correct.

As you might suspect, there were chuckles around the room-in our opinion primarily because, after more than 90 minutes of convoluted verbiage, it was such a relief to hear someone speak a simple declarative sentence!

On July 6, 2004, another straight-speaker, Warren Buffett, again chimed in, this time in a Washington Post article, where his sharp wit clearly communicated his views on the bill (Buffet 2004):

Until now the record for mathematical lunacy by a legislative body has been held by the Indiana House of Representatives, which in 1897 decreed by a vote of 67 to 0 that pi -- the ratio of the circumference of a circle to its

\footnotetext{
${ }^{10}$ Note that if we assume zero volatility, the value of the option drops precipitously. In fact, if the expected risk-free rate is equal to the expected dividend yield, the value drops to zero.

${ }^{11}$ U.S. Senate Committee on Homeland Security and Governmental Affairs Subcommittee on Federal Financial Management, Government Information, and International Security. "Oversight Hearing on Expensing Stock Options: Supporting and Strengthening the Independence of the Financial Accounting Standards Board." April 20, 2004.
} 
diameter -- would no longer be 3.14159 but instead be 3.2. Indiana schoolchildren momentarily rejoiced over this simplification of their lives. But the Indiana Senate, composed of cooler heads, referred the bill to the Committee for Temperance, and it eventually died.

... House members who wish to escape the scorn of historians should render the Senate's task moot by killing the [stock option] bill themselves. Or if they are absolutely determined to meddle with reality, they could attack the obesity problem by declaring that henceforth it will take 24 ounces to make a pound. If even that friendly standard seems unbearable to their constituents, they can exempt all but the fattest five in each congressional district from any measurement of weight.

In the late 1990s, too many managers found it easier to increase "profits" by accounting maneuvers than by operational excellence. But just as the schoolchildren of Indiana learned to work with honest math, so can optionissuing chief executives learn to live with honest accounting. It's high time they step up to that job.

Baker's bill passed the House on July 20 with a vote of 312 to 111, and was referred to the Senate.

However, in contrast to the situation ten years before, a group of influential senators, along with others such as Federal Reserve Chairman Alan Greenspan and Treasury Secretary John Snow, supported the FASB's proposed accounting for stock options and were actively opposed to Congressional intervention (see, e.g., Day 2004; Schroeder 2004). ${ }^{12}$ Due in part to the recent frauds and to the support of these senators, the SEC was able to stand fast in the face of all this opposition. On August 19, 2004, SEC Chairman William Donaldson wrote a letter to Senate Majority Leader Frist and 16 other senators. Interestingly, the letter did not address any of the various arguments being made by interested parties on either side of the stock option debate, but instead focused on the FASB's independent and thorough standard-setting process as being something worth preserving. In part, he states:

The FASB's standard-setting process with respect to the expensing of stock options is in the final stages of what has been a very long and exhaustive process. Because it is critical to the restoration of public confidence in the integrity of financial reporting in the United States that the independence, expertise, and open processes of the FASB be honored and supported, I believe strongly that the FASB's consideration of this proposed standard regarding stock options should be allowed to run its full course.

\section{Statement of Financial Accounting Standards No. 123 Revised (SFAS No. 123R)}

Victory at last! In December 2004, the FASB prevailed and the revised version of SFAS No. 123 was passed. Thus, after more than 20 years of wrangling, US GAAP would now require companies to expense the fair value of stock options granted to employees as part of their compensation. You can probably imagine the satisfaction felt by FASB as they (finally) drafted the following paragraph of SFAS No. 123R (FASB 2004, I/1):

This statement requires that the cost resulting from all share-based payment transactions be recognized in the financial statements. This statement establishes fair value as the measurement objective in accounting for sharebased payment arrangements...

Thus, the first accounting question presented in the case — should employee stock options be recognized as an expense - had now finally been answered with a resounding "YES"!

Since companies were already determining fair values of their stock options for the footnote disclosures required by the original SFAS No. 123, you may be thinking that SFAS No. 123R would be relatively straightforward to implement. However, as many auditors will admit privately — and some even publicly - there is a higher standard for values that are recognized in the financial statements than for values reported in footnote disclosures. Thus, the pressure on companies and auditors to deal with option valuation increased substantially.

\footnotetext{
${ }^{12}$ In fact, the Senate sent the stock option bill to the Committee on Banking and Urban Affairs, and it hasn't been heard from since.
} 
Much of the basic guidance related to measurement is similar under SFAS No. 123 and SFAS No. 123R. Both versions require fair values to be estimated on the grant date. Both versions advocate the use of option valuation models to determine the fair value — or P - of the options. Both versions advocate that $\mathrm{Q}$ should be based on the number of options that eventually vest. Both versions allocate total compensation cost over the periods that services are rendered, which is typically the vesting period. Both provide guidance for more complex options that incorporate conditions on P and/or Q (e.g., indexed options). However, in many cases, the language in SFAS No. $123 \mathrm{R}$ is more detailed and/or clearer about some issues.

\section{IMPLEMENTING THE NEW STANDARD}

As noted earlier, one implication of SFAS No. 123R is that the valuation of employee stock options suddenly became much more serious business. Companies and their auditors were much more concerned about issues such as how to determine (and audit) the assumptions used in the stock option valuation models. The SEC was also concerned, as they were the group that actually had to enforce the new rules. Donald Nicolaisen, then Chief Accountant of the SEC, stated in June of 2004:

While some level of implementation guidance undoubtedly will be provided by the FASB, I am sensitive to concerns about the range of estimates that may be inserted into the models that calculate the fair value of employee stock options. Accordingly, if the FASB issues a final standard, I am committed, as is Alan Beller, Director of the Division of Corporation Finance, that to the extent necessary or appropriate the Office of the Chief Accountant and the Division will work with registrants and auditors to provide guidance regarding acceptable practices for determining estimates of volatility and other factors required by option pricing models, as well as certain other disclosure issues. Furthermore any such guidance would be provided after the final standard is adopted and give registrants sufficient time to implement the standard. ${ }^{13}$

\section{Staff Accounting Bulletin (SAB) No. 107}

Nicolaisen made good on this promise and the SEC issued Staff Accounting Bulletin (SAB) 107 in March of $2005 .{ }^{14} \mathrm{SAB} 107$ provided substantial guidance on the details of how to value ESOs, particularly how to determine the inputs to the valuation models. SAB 107 also addressed another interesting issue related to disclosure: the presentation of non-GAAP measures related to employee stock options. You are probably wondering what a non-GAAP measure is and why it would relate to stock options.

The SEC defines a non-GAAP measure as a numerical measure of a registrant's historical or future financial performance, financial position or cash flows that:

- $\quad$ excludes amounts...that are included in the most directly comparable measure calculated and presented in accordance with GAAP in the statement of income, balance sheet or statement of cash flows (or equivalent statements) of the issuer; or

- $\quad$ includes amounts...that are excluded from the most directly comparable measure so calculated and presented (SEC 2003a, qIII. A. 2. a.).

The SEC's concern is that investors could be misled by measures that appeared similar to GAAP measures but were calculated differently. Thus, the SEC requires extensive disclosures, including reconciliations, when nonGAAP measures are used. They also prohibit some uses of these measures, such as "presenting non-GAAP financial measures on the face of the registrant's financial statements prepared in accordance with GAAP or in the accompanying notes."

\footnotetext{
${ }^{13}$ Open Roundtable Discussion with Respondents to the Financial Accounting Standards Board Exposure Draft, Share-Based Payment, Opening Statement by Donald T. Nicolaisen, Chief Accountant, U.S. Securities and Exchange Commission, Thursday, June 24, 2004, Palo Alto, California.

${ }^{14}$ It was unusual for the SEC to issue a SAB so quickly after a new standard was issued. This quick response indicates the level of difficulty the SEC staff anticipated with the implementation of SFAS No. 123R.
} 
The issue of non-GAAP measures arose almost immediately upon passage of the revised SFAS No. 123. Ironically, many of the same companies that had grumbled about providing the pro forma disclosures in their footnotes under the original SFAS No. 123 were now very interested in including pro-forma income statements in their filings - however, now the pro-formas eliminated the charge for stock options under SFAS No. 123R (Seitz 2005). As a result, the SEC included guidance in SAB 107 about when and how such pro-forma information was permitted in filings.

This is especially interesting when combined with analyst responses to SFAS No. 123R. You may recall from earlier in the case that, back in 2001, most analysts seemed to be lobbying for companies to expense stock options. However, once SFAS No. 123 was revised to require such expensing, substantial diversity developed in the analyst community about how to treat this expense. Part of this confusion stemmed from the non-GAAP disclosures described above that now excluded stock compensation expense. Some analysts used the pro-forma guidance and excluded stock-option expense from their estimates, while others based their estimates on earnings reported under GAAP and included stock option expense. Some folks are never happy!

This confusion prompted some Wall Street firms to mandate that analysts take the cost of options into account (Gullapalli 2005). However, to add to the confusion, the companies that compile consensus analyst estimates - such as Thomson First Call, Reuters, and Zachs Investment Research-began reporting consensus estimates based on how a majority of the analysts that follow a firm calculate their earnings estimates. This outcome was likely not what standard-setters had in mind as they valiantly fought to increase the transparency of financial reporting for stock options. Representatives from the analyst firms "argue that the problem lies with managers of mutual funds, pension plans and other institutional investors who don't support options expensing because lower earnings-per-share figures could dent valuations for stocks they own" (Gullapalli 2005).

\section{CONCLUSION}

Is the stock option accounting debate over? What is the next financial "innovation" that will be designed to get around the accounting rules? The only thing we can say with certainty is that the design and use of employee stock options - and the accounting for such options - will likely continue to evolve.

\section{AUTHOR INFORMATION}

Denise A. Jones is Associate Professor of Accounting at The College of William and Mary. She completed her PhD in Accounting at University of Colorado in 2000. Her research interests include voluntary disclosure and the role of accounting information in firm valuation, and she has published a number of articles in such leading journals as The Accounting Review, Contemporary Accounting Research, Journal of Accounting and Public Policy, and Journal of Management Accounting Research. E-mail: denise.jones@mason.wm.edu.

Kimberly J. Smith is Professor and KPMG Accounting Fellow at The College of William and Mary. She completed her Ph.D. in Business Administration at the University of Maryland in 1989. In 2003-2004, she served as the Academic Accounting Fellow at the Office of the Chief Accountant of the U.S. Securities and Exchange Commission. Her research interests include CEO pay and performance, and off-balance sheet arrangements, and she has published a number of articles in leading journals such as The Accounting Review, Journal of Business, Accounting Organizations and Society, Journal of Management Accounting Research, and Issues in Accounting Education. E-mail: kim.smith@mason.wm.edu. Corresponding author.

\section{REFERENCES}

1. Accounting Principles Board of the American Institute of Certified Public Accountants (1972). Accounting for Stock Issued to Employees. Accounting Principles Board (APB) Opinion No. 25. New York, NY: AICPA.

2. American Institute of Certified Public Accountants (1953). Restatement and Revision of Accounting Research Bulletins. Accounting Research Bulletin (ARB) No. 43. New York, NY: AICPA.

3. Beresford, D. (1995). "How should the FASB be judged?” Accounting Horizons 9: 56-61. 
4. Bettis, J., Bizjak, J., Lemmon, M. (2005). "Exercise behavior, valuation, and the incentive effects of employee stock options.” Journal of Financial Economics 76: 445-470.

5. Black, F., Scholes, M. (1973). "The pricing of options and corporate liabilities." Journal of Political Economy 81 (3), 637-654.

6. Bomeli, E. (1962). "Stock option plans_-full disclosure." The Accounting Review 37: 743-744.

7. Botosan, C., Plumlee, M. (2001). "Stock option expense: the sword of Damocles revealed." Accounting Horizons 15: 311-327.

8. Business Wire (2001). "Analysts, portfolio managers want employee stock options expensed on income statements, global AIMR survey shows.” Business Wire (November 19).

9. Brown, K. (2001). "Options overdose—now, some hope for their stock to tank." The Wall Street Journal (June 4).

10. $\quad$ Buffet, W. (2004). "Fuzzy Math and Stock Options.” The Washington Post (July 6).

11. Buffet, W. (1999). Chairman's Letter to Shareholders. Berkshire Hathaway Inc. 1998 Annual Report. March 1. Available at: http://www.berkshirehathaway.com/letters/1998htm.html

12. Call, D. (1969). "Some salient factors often overlooked in stock options." The Accounting Review 44: 711719.

13. Carpenter, J. (1998). "The exercise and valuation of executive stock options.” Journal of Financial Economics 48: 127-158.

14. Ciccotello, C., Grant, C., Grant, G. (2004). "Impact of employee stock options on cash flow." Financial Analysts Journal 60: 39-46.

15. Day, K. (2004). "Senators resist blocking FASB; Accounting Board close to ruling on expensing stock options." The Washington Post (January 9).

16. Dillavou, E. (1945). "Employee stock options.” The Accounting Review 20: 320-326.

17. DiStefano, J. (2002). "In backlash of corporate scandal, companies expense stock-option grants." The Philadelphia Inquirer (August 11).

18. Financial Accounting Standards Board (2004). Share-Based Payment. Statement of Financial Accounting Standards (SFAS) No. 123(R). Norwalk, CT: FASB.

19. Financial Accounting Standards Board (2000a). Accounting for Certain Transactions Involving Stock Compensation. FASB Interpretation (FIN) No. 44. Norwalk, CT: FASB.

20. Financial Accounting Standards Board (2000b). Issues Related to the Accounting for Stock Compensation under APB Opinion No. 25 and FASB Interpretation No. 44. Emerging Issues Task Force (EITF) 00-23. Norwalk, CT: FASB.

21. Financial Accounting Standards Board (1995). Accounting for Stock-Based Compensation. Statement of Financial Accounting Standards (SFAS) No. 123. Norwalk, CT: FASB.

22. Financial Accounting Standards Board (1978). Accounting for Stock Appreciation Rights and Other Variable Stock Option or Award Plans. FASB Interpretation (FIN) No. 28. Norwalk, CT: FASB.

23. Gullapalli, D. (2005). "Tracking the numbers/ outside audit: Wall Street turns blind eye to results of option expensing." The Wall Street Journal (July 12).

24. Hamm, S., Borrus, A., McNamee, M. (2003). "Will expensing cost the US jobs? Tech execs Claim new accounting rules could force them to send work overseas." Business Week (December 22).

25. Hitt, G., Schlesinger, J. (2002). "Stock options come under fire in the wake of Enron's collapse." The Wall Street Journal (March 26).

26. Marquardt, C. (2002). "The cost of employee stock option grants: an empirical analysis." Journal of Accounting Research 40: 1191-1217.

27. Meyer, A., Fassier, W. (2004). "The stock-option nightmare: shareholders can avoid it by calculating 'unfettered free cash flow." Barron's (February 23).

28. Ratliff, P. (2005). "Reporting employee stock option expenses: is the debate over?" The CPA Journal 75: 38-43.

29. Securities and Exchange Commission (2003). Final Rule: Conditions for Use of Non-GAAP Financial Measures. FR-65.

30. Securities and Exchange Commission (2005). Staff Accounting Bulletin No. 107 (17 CFR Part 211).

31. Seitz, P. (2005). "Firms start to expense options, but many dismiss new figures; techs urge analysts to use pro forma results; Microsoft is exception.” Investor's Business Daily (September 7). 
32. Shao, M. (1994). "Stock-option plan draws fire, Standards Board proposes to deduct cost from profits." The Boston Globe (March 8).

33. Schroeder, M. (2004). "Moving the market: House passes curb on expense rules for stock options." The Wall Street Journal (July 21).

34. Schroeder, M., Simon, R. (2001). "Tech firms object, as SEC gets tougher on their practice of repricing options" Wall Street Journal (February 7).

35. Talley, K. (2005). "Stock option reporting to take greatest toll on tech cos." Dow Jones News Service (April 7).

\section{TEACHING SUGGESTIONS}

This case differs from many cases on stock options, as the emphasis of the case is on the process whereby accounting standards evolve over time in response to changes in the political environment, changes in the business environment, and the development of innovative transactions designed to "get around" accounting standards. This is an important concept that many students may not fully appreciate, as they have been mainly exposed to the accounting rules as they exist at a point in time. Knowing why the current accounting rules exist in their present form is important to understand the limitations of the current accounting standards, as well as how they are likely to change in the future.

We wrote this case for the core financial accounting module in our Master of Accounting Program. After our classroom implementation of the case, we obtained feedback from the participating students by requesting their comments (for which they received extra-credit points - regardless of the content of their comments). We asked for their overall views on the case, and also asked specific questions about whether they thought the case too long, and if so, what they would recommend eliminating. We also asked them to comment on the clarity of the writing and the difficulty of the numerical exercises. Sample student responses are presented below.

I certainly walked away from the case with a better idea of the battle the FASB goes through before any accounting changes are put in place. While the case is long, I had trouble trying to single out any part that I considered superfluous. It made sense, I like that you kept it in primarily in historical order. That allowed us to see the progression of standards.

I could not believe how much influence politics could have on setting accounting standards to the point where Joe Lieberman was pushing a bill trying to dissolve the FASB! The examples of legislation were really good. I even think adding some of the comment letters people sent into the FASB as exhibits could enhance explaining this political environment. I can only imagine what people were sending in, like accusing the FASB of taking away their stock options plans and ruining their lives by setting an accounting standard. Those letters could be interesting exhibits for students.

I had NO idea how political something like setting accounting standards could get and after I read the case I was thankful there is a FASB instead of Congressmen setting accounting standards. The case work on top of in class discussion made for a pretty solid understanding of the standards for stock options.

Suggestions for teaching the case are presented below by section.

\section{Introduction}

If students have never been exposed to options, the instructor may need to draw the option payoff picture that is commonly shown in many textbooks. The main point to be emphasized is that the option is one-sided; the holder may benefit, but will not lose. In addition, with inexperienced students, the instructor will likely want to talk about the parameters that affect the option's value, and make sure the students understand the intuition for why some variables increase the option's value, while others decrease it. It is also important to emphasize that ESOs differ rather substantially from exchange-traded options. 
It is critical to set up in the minds of the students that differences across ESOs affect the option's value, and may also make this value more difficult to estimate. For example, students should intuitively see that an option with an exercise price that increases over time should be worth less than an option with a fixed exercise price. However, it is very important for the students to see that such changes in an option's terms make it more difficult to value. It is also very important that the students take the time to wonder why companies would create such options, and for the instructor to emphasize that such options may do a superior job of providing incentives to employees (e.g., to exceed the performance of the market instead of being rewarded for market increases over which the employee has little influence). The owner perspective will sometimes need to be emphasized, as students tend to take the perspective of the employee receiving the options.

\section{Accounting Issues Related to Stock Options}

The instructor should walk through the example if enough time is available. The basic issues of whether to recognize ESOs as expense, how to measure the expense, how to allocate the expense across periods, and whether to recognize equity or a liability are pervasive throughout the case and the students should be certain they can answer these questions for each of the standards discussed. This section also sets up a critical issue that accountants have always struggled with: the difficulty accounting standard setters have in staying ahead of the latest financial innovations, which some feel are often designed with the express intent of circumventing accounting rules.

\section{Early Guidance on Stock Option Accounting}

It is important to note the different definitions of fair value in these standards, as people often overlook the fact that APB 25 was intended to be an improvement over ARB 43. However, the time value of the option was still ignored by APB 25, as it had been in ARB 43. This is a good time to emphasize that even stock options with no intrinsic value do have value (i.e., time value) — but at the time it was not thought practicable to measure that value. Finally, this section introduces the difference between "fixed" vs. "variable" ESO accounting. It is important to walk through this example as well. This is also a good point to begin the discussion of how accounting can affect managers' actions. For example, a number of option plans were set up after APB 25 so that the exercise price and number of options were fixed in order to qualify for "fixed" accounting. This gives rise to an interesting question of whether this is an optimal way to structure a compensation plan.

The discussion of FIN 28 introduces a new instrument that was created-the Stock Appreciation Right (SAR) - and how the then-current accounting guidance was not clear about how to treat it. Many students will not have had much exposure to FASB Interpretations, so this is a good opportunity for a quick side-bar about what purpose Interpretations served and how they were created. It is important that the students understand that the advent of SARs brought up two issues. The first is the inconsistency of accounting for a stock option using fixed accounting, but using variable accounting for a SAR with virtually identical terms (except that the option is settled for stock and the SAR for cash). This inconsistency is part of the reason that the Board decided to reconsider the accounting for employee stock options. The second issue brought up by SARs was whether paying employees in cash should mean that the "credit" side of the journal entry recording compensation expense should be a liability, rather than equity. This provides a good opportunity to point out to students that many standards are interrelated, and it is sometimes quite a bit of work to ensure that new guidance doesn't introduce inconsistency, rather than reduce it. A related point is that getting side-tracked, as the Board did on this liability issue, is one of the reasons that standardsetting takes such a very long time.

\section{Stock Option Accounting Revisited}

If the students have had no prior exposure to the valuation of stock options, this may be the appropriate point to stop and look at both models. These models are described in numerous finance textbooks. We would recommend looking at the binomial model first, as it lays out the logic of valuing a stock option. Then the Black Scholes model can be presented as a continuous version of the binomial. If the instructor projects the models on the screen in class, it is easy to discuss whether each parameter leads to increases or decreases in the option value. 
This section then describes the battle that ensued when SFAS No. 123 was introduced. Here the students begin seeing "behind the standards," so to speak, to the process that produces them. The instructor may want to encourage the students to go to http://www.fasb.org/facts/index.shtml\#topics to read about the process by which standards are created. However, the political aspects of this process are illustrated quite well in this story of employee stock option accounting. The FASB is not all-powerful, though it often seems that way to students, and may be "put out of business" by the SEC, or by Congress itself. As an aside, many students will be surprised to hear that accounting issues caused demonstrations, but this is indeed the case.

It is important here to ask students if they believe that recognizing employee stock options as an expense would make any difference. Given that most of these options were argued to have no direct cash consequences, what do the students believe would happen? Would stock prices drop? Would capital become more expensive? Would businesses fail? Would businesses really cease offering stock options if they were forced to claim the expense? If the answer to any of these questions is "yes," what does that imply about theories of stock market efficiency?

A related issue is the fact that many companies engage in buying back their own stock to support the exercises of employee stock options. Does this change the students' minds about any of the above questions? Be sure to note that buybacks of stock are currently disclosed in the Statement of Shareholder Equity.

This section is concluded with a discussion of the compromise position the FASB took with the original SFAS No. 123. This provides a context for a rich discussion. Did the Board roll over? Were they simply cowards? Was discretion the better part of valor? Did their solution provide the most important information to investors? Is recognition really that much better than disclosure? Is disclosure better than nothing? The instructor should be prepared for a variety of opinions. It is interesting to ask the students how they think they would have voted if they had been Board members.

\section{Accounting Consequences of Stock Market Decline}

The instructor may want to take a moment to look again at the Black Scholes model and impress upon the students that repricing is indeed providing value to the employee. To do this, we recommend the instructor show the following example:

(1) Write down the value for an option with a ten year life (the typical life of an ESO), where stock and strike prices are $\$ 50.00$, volatility is 30 percent, risk free rate is three percent, and dividend yield is one percent. This value is $\$ 19.38$. Label this as year one.

Write down the value five years later (i.e., when the remaining life is now five years), when the stock price has dropped to $\$ 25.00$, but assuming all the other parameters have stayed constant (not likely, but a reasonable simplification). This shows the value of the option immediately before repricing. That value is $\$ 2.14$.

(3) Then the instructor can show the effects of repricing by changing the strike price to $\$ 25.00$ (assuming that the option would be repriced at-the-money) and comparing the values. The option increases dramatically in value immediately upon repricing, from the $\$ 2.14$ above to $\$ 7.14$.

It seems rather obvious that the employee is given something of value when his or her options are repriced. The question is what to do with the increment (i.e., the $\$ 5.00$ in the example above).

FAS 123 required that the $\$ 5.00$ be recognized as incremental compensation expense. However, it was not clear how to apply APB 25 to this scenario. One could argue that a new measurement date had occurred and that compensation expense should be recognized. However, if the option was repriced to be at-the-money, wasn't the amount of compensation expense still zero? And what about the fact that these options had been accounted for as fixed options for the last five years? Was that an error? Should the company go back and restate their financial statements so that they used variable accounting? Many questions arose as a result of the wave of option repricings - but few clear and unequivocal answers were available from APB 25, which was the accounting standard most companies were still using. 
It may be interesting to note that the SEC clamped down on repricings using their standard weaponrequired disclosure. In their worry about investors being hurt by repeated repricings, the SEC required that any company engaging in an option repricing must disclose all repricings performed during the last ten years! Given the rising unpopularity of repricings, viewed as a way to let employees "off the hook" when investors were losing money, this requirement caused some hesitation in companies considering repricing their ESOs.

The sequence of events related to FIN 44 and EITF 00-23 make a great illustration of the dynamic process that accounting standard setting follows. Specifically, the fact that companies immediately began issuing $6+1$ options after the issuance of FIN 44 shows what companies are willing to do to assure a certain accounting treatment. This becomes even more interesting when EITF 00-23 is considered. The fact that it covers 51 separate issues is interesting in itself. We chose to focus on the issue of indirectly compensating employees for price changes in the six month period (between the time the old options were cancelled and the time they were replaced) by issuing options that were already in the money. It is a great example of changing the terms of a contract in an attempt to circumvent accounting standards. It also hits home the fact that accountants cannot really do a good job if they do not understand the economics behind various transactions. Finally, this is a good place to introduce the idea of principles-based vs. rules-based standards as it is a great example of the consequences of a "bright line test."

\section{Stock Option Accounting: Round Two}

One important point to emphasize here is that the arguments about stock option accounting did not change, but what did change is the political climate. One other thing to note here is that the IASB proposed recognizing share-based payments as an expense in 2001. This could lead to an interesting side discussion about the role of US accounting standards in a global economy and the current trend toward international convergence. An assignment or case about implementing the current standards is a good follow-up to this case. A reading of FASB Codification Topic 718, or a case on current ESO accounting could also be assigned.

\section{Implementing the New Standard}

Two important points are made in this section. First, the SEC has a very active role in the financial reporting of public companies, particularly related to the information they disclose and how they disclose it. Second, there is substantial disparity in how the analyst community treats stock option expense. Some analysts consider it an expense and some are focusing their earnings guidance on earnings excluding stock compensation. At this point it might be interesting to discuss why analysts would ignore stock compensation. This is particularly interesting since many in the financial community consider options to have a cash cost due to their dilutive nature causing companies to repurchase shares of their own stock. News articles discussing this idea include Meyer and Fassler (2004) and Ciccotello et al., (2004). 